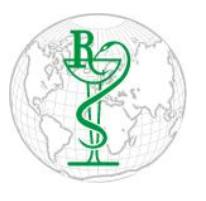

INDO GLOBAL JOURNAL OF

PHARMACEUTICAL SCIENCES

ISSN 2249- 1023

\title{
Antioxidant and Antiglycation Potential of Essential Oil Extracts from Leaves and Stems of Erythroxylum monogynum Roxb.
}

\author{
Bindu G. ${ }^{1}$, Ravi Kiran S. ${ }^{2 *}$ \\ ${ }^{1} R \& D$ Centre, Bharathiar University, Coimbatore - 641046, Tamilnadu, India \\ ${ }^{2}$ Department of Biochemistry, Aurora's Degree \& PG College, Chikkadapally, Hyderabad - 500020, Telangana, India
}

Address for Correspondence: Ravi Kiran S, srksuripeddi@gmail.com

Received:
03.12.2019
Accepted:
16.03.2020
Published:
20.12 .2020
Keywords
Essential oil
composition,
Erythroxylum
monogynum,
DPPH
scavenging
assay,
Xanthine oxidase
inhibitory
potential and
Anti-glycation
activity.

\section{Received:}

03.12.2019

Keywords

Essential oil

composition,

Erythroxylum

DPPH

scavenging

assay,

inhibitory

potential and

activity.

\begin{abstract}
Purpose: The main objective of this study is to assess the anti-oxidant and anti-glycation potential of essential oil from leaves and stems of E. monogynum. Methods: The essential oil from leaves and stems was obtained by hydro distillation and the chemical composition was determined by GC-FID and GCMS. Further, the total phenolic and flavonoid contents were also estimated in all the extracts. Both the essential oils and solvent extracts were screened for anti-oxidant activity using DPPH scavenging, $\mathrm{H}_{2} \mathrm{O}_{2}$ scavenging, NO scavenging and Xanthine oxidase inhibitory assays. Subsequently, all the samples were investigated for anti-glycation potential. Results: The chemical composition of essential oils was determined by GC and GC-MS. The major components in leaf oil were limonene, pregeijerene, geijerene, isobornyl acetate, germacrene D and farnesol while the major components identified in the stem oil include limonene, pregeijerene, Methyl Eugenol, germacrene D and Farnesol. The total phenolic and flavonoid contents were found to be 36.23 and $34.47 \mathrm{mg}$ of gallic acid/gm \& 16.71 and $14.17 \mathrm{mg}$ of quercetin /gm respectively for leaf and stem essential oil extracts. The leaf essential oil exhibited potent anti-oxidant activity of $90.33 \%$ and $90 \%$ for DPPH and $\mathrm{H}_{2} \mathrm{O}_{2}$ scavenging assays respectively. Among all the extracts tested, leaf oil showed excellent NO scavenging activity with $\mathrm{IC}_{50}$ of $58.64 \mu \mathrm{g} / \mathrm{ml}$. Further higher inhibitory effect of more than $90 \%$ inhibition of advanced glycation end products (AGE) formation was observed at $100 \mu \mathrm{g} / \mathrm{ml}$. Conclusion: The results obtained are remarkable proving that this plant contains a valuable source of phytoconstituents acting as antioxidants and anti-glycation agents which upon further purification and standardization can be implicated in the treatment of stress disorders, gout and diabetes. () 2020 iGlobal Research and Publishing Foundation. All rights reserved.
\end{abstract}

Cite this article as: Bindu, G.; Ravi Kiran, S. Antioxidant and antiglycation potential of essential oil extracts from leaves and stems of Erythroxylum monogynum Roxb. Indo Global J. Pharm. Sci., 2020; 10(4): 77-87. DOI: http://doi.org/10.35652/IGJPS.2020.104011 .

\section{INTRODUCTION}

In human beings, a large number of free radicals or reactive oxygen species (ROS) are produced in the body due to exogenous chemicals or various metabolic activities causing oxidative stress damage. Oxidative stress plays a chief role in the pathogenesis of aging and degenerative diseases such as atherosclerosis, diabetes, cardiovascular diseases and cancer [1-2]. The protection from ROS can be achieved to some extent with the help of enzyme systems such as superoxide dismutase, catalase and Glutathione peroxidase. Further antioxidant compounds such as ascorbic acid, tocopherol, phenolic acids, polyphenols and flavonoids offer a significant level of protection. Free radicals are degraded to non-reactive forms by enzymatic and non-enzymatic antioxidant defenses produced in the body and others supplied by the diet.

Medicinal plants and products are being used in the treatment of various cellular and metabolic diseases such as diabetes, obesity and cancer etc. Several studies have shown that plant derived antioxidant nutraceuticals scavenge free radicals and modulate oxidative stress-related degenerative effects [3-4] Free radicals have been implicated in many diseases such as cancer, atherosclerosis, diabetes, neurodegenerative disorders and aging [3-4]. Previous research reports suggest that higher intake of antioxidant rich food is associated with decreased 


\section{Indo Global Journal of Pharmaceutical Sciences, 2020; 10(4): 77-87}

risk of degenerative diseases particularly cardiovascular diseases and cancer [5]. Among these, essential oils are a mixture of complex natural compounds of medicinal and aromatic plants comprising mostly of volatile constituents with characteristic aroma and are employed in drug, food and perfumery industries [6]. These have received much attention and this attracted many scientists to use essential oils antioxidant and anti-glycation activities thus leading to the development of novel lead products for the treatment of oxidative stress and diabetes. Essential oils have been studied for their potential antioxidant capacities which can be attributed to the presence of phenolics, flavonoids and terpenes that potentially contribute to the free radical scavenging activity [7-9]. Many herbal and plant infusions frequently used in domestic medicine have anti-oxidative and pharmacological properties connected with the presence of phenolic compounds.

Erythroxylum monogynum (E. monogynum) commonly known as Red Cedar is a tropical tree belonging to the family Erythroxylaceae. Native to India and Sri Lanka, the plant is known to have a high medicinal value such as in curing many diseases such as stomachic, dyspepsia, fever, and dropsy in Ayurveda medicine [10]. As a part of the screening program of natural products from south India, E. monogynum plant was chosen to explore the potential antioxidant and anti-glycation activities of essential oil extracts along with correlation with that of total phenolic and flavonoid contents. Therefore, we here in present the results of our investigative study.

\section{MATERIALS AND METHODS}

\section{Plant Material}

\section{Chemicals and Standard Compounds}

The chemicals and solvents required for the study were of analytical grade and procured from Merck, India. The standard compounds such as allopurinol, ascorbic acid and gallic acid were procured from Sigma-Aldrich, Bangalore, India.

\section{Sample collection}

Leaves of E. monogynum were collected from the forest of Nallamala Forest, near Tirupathi, Andhra Pradesh, India where a sample specimen was deposited at the herbarium of Department of Botany, Osmania University, Hyderabad (No. OUBOT 9784).

\section{Essential oil extraction}

The air-dried leaves and stems of E. monogynum were subjected to hydro distillation in a Clevenger apparatus for 4 hr. The oil thus obtained was dried over anhydrous sodium sulphate and stored at $4{ }^{\circ} \mathrm{C}$ under nitrogen until further use. The oil content was expressed as $\mathrm{ml} / 100 \mathrm{~g}$ of dried leaves. The oil thus obtained was analyzed by Gas chromatography (GC) and Gas chromatography Mass spectrometry (GC-MS).

\section{Solvent Extraction}

The leaves and stems were collected, transferred into a flask and soaked separately in Pet ether, and ethanol for extraction for about $8 \mathrm{~h}$. After that, the leaves were mildly homogenized in a mortar and pestle and the extract was filtered. The separated solvent layers were dried over anhydrous $\mathrm{Na}_{2} \mathrm{SO}_{4}$, evaporated under vacuum. The light green and pale yellow extracts thus obtained were stored in a refrigerator at $4{ }^{\circ} \mathrm{C}$ for further analysis.

\section{GC Analysis}

Analysis was carried out, on a Varian-gas chromatograph equipped BP-1 capillary column $(30 \mathrm{~m}$ X $0.2 \mathrm{~mm}$ i.d., film thickness $0.25 \mu \mathrm{m}$ ). The carrier gas was helium and employed at a flow rate of $1.0 \mathrm{ml} / \mathrm{min}$ with 8 p.s.i inlet pressure. The temperature was programmed from $60^{\circ} \mathrm{C}$ to $220^{\circ} \mathrm{C}$ at a ramp rate of $5^{\circ} \mathrm{C} / \mathrm{min}$ and a final hold time of $6 \mathrm{~min}$. The temperature of the injector and detector was maintained at $250^{\circ} \mathrm{C}$ and $300^{\circ} \mathrm{C}$ respectively. $0.2 \mu l$ of the sample was injected with 1:100 split ratio.

\section{GC-MS Analysis}

An Agilent 6890 GC equipped with HP-5 capillary column $(30 \mathrm{~m} \times 0.25 \mathrm{~mm} \mathrm{X} 0.25 \mu)$ and a $5973 \mathrm{~N}$ mass selective detector was used for the analysis. The oven temperature was programmed from $50^{\circ} \mathrm{C}$ to $280^{\circ} \mathrm{C}$ at a ramp rate of $4^{\circ} \mathrm{C} / \mathrm{min}$ with a final hold time of $5 \mathrm{~min}$. The temperature of Inlet and interface was maintained at $250^{\circ} \mathrm{C}$ and $280^{\circ} \mathrm{C}$ respectively and helium at a flow rate of $1.0 \mathrm{ml} / \mathrm{min}$ (constant flow) was used as a carrier gas. $0.2 \mu \mathrm{l}$ of the sample was injected under a split of 20:1. EIMS: electron energy, 70ev. The Ion source and quadrupole temperatures were maintained respectively at $230^{\circ} \mathrm{C}$ and $150^{\circ} \mathrm{C}$.

\section{Identification of Compounds}

Identification of individual components was carried out by comparing the retention indices (RI) of the peaks determined on a BP-1 column using a saturated mixture of $\mathrm{C}_{8}-\mathrm{C}_{22} \mathrm{n}$ alkanes as a reference with linear interpolation and also with those of literature [11-12]. Further identification was accomplished by GC-MS by comparing their mass spectra with mass spectral databases such as Wiley and NIST which are residents in the system [12-13].

\section{Preliminary phytochemical screening}

The preliminary phytochemical screening was done according to the standard qualitative chemical methods [14] wherein, all 


\section{Indo Global Journal of Pharmaceutical Sciences, 2020; 10(4): 77-87}

the extracts were screened for the presence of carbohydrates, alkaloids, terpenoids, anthraquinones, tannins, sterols, and flavonoids.

\section{Determination of total phenolic content}

The total phenolic content was determined by FolinCiocalteau method [15]. To an aliquot of $100 \mu \mathrm{l}$ of the plant extract $(1 \mu \mathrm{g} / \mathrm{ml}), 1 \mathrm{M} \mathrm{Na} 2 \mathrm{CO} 3$ and Folin-Ciocalteau reagent were added. The color developed after 15 minutes of the reaction in dark was measured at $760 \mathrm{~nm}$ against reagent blank prepared in the same manner and gallic acid was served as the reference standard. Total phenolics were determined as milligrams of gallic acid equivalents per gram of sample by computing it with a calibration curve. All the experiments were performed in quintuplicate.

\section{Determination of total flavonoid content}

Total flavonoid content was measured with the colorimetric assay published in the literature [16] and performed in quintuplicate. To the appropriately diluted ethanol extract (1ml), $0.2 \mathrm{ml}$ of $10 \%$ aluminum chloride, $0.2 \mathrm{ml}$ of $1 \mathrm{M}$ potassium acetate and $5.6 \mathrm{ml}$ of distilled water were added and incubated at room temperature for 30 minutes. The absorbance of the reaction mixture was measured at $420 \mathrm{~nm}$ and the total flavonoids were determined from the calibration curve as milligrams of quercetin equivalents per gram of sample.

\section{Free radical Scavenging Activity (FRSA) using DPPH}

The free radical scavenging ability of extracts of $E$. monogynum was determined using 1,1-diphenyl2picrylhydrazyl (DPPH) radical scavenging method as per the literature reports [17]. Ascorbic acid served as a standard compound. The reaction mixture contained $2 \mathrm{ml}$ of 1.0 $\mathrm{mmol} / \mathrm{L} \mathrm{DPPH}$ solution in methanol and $1.0 \mathrm{ml}$ of extract (10$500 \mu \mathrm{g} / \mathrm{ml}$ ) and standard compound. The mixture was incubated for $20 \mathrm{~min}$ at $37^{\circ} \mathrm{C}$. The decrease in the absorbance was measured at $517 \mathrm{~nm}$ against a reagent blank. The scavenging ability was calculated using the following formula. All experiments were performed in quintuplicate.

Free radical scavenging activity $(\%)=\left(\mathrm{A}_{\mathrm{s}}-\mathrm{A}_{\mathrm{t}}\right) / \mathrm{A}_{\mathrm{s}} \times 100$

Where $\mathrm{A}_{\mathrm{s}}=$ Absorbance of standard compound

$$
\mathrm{A}_{\mathrm{t}}=\text { Absorbance of sample }
$$

\section{Free radical Scavenging Activity (FRSA) using Hydrogen} Peroxide $\left(\mathrm{H}_{2} \mathrm{O}_{2}\right)$

The hydrogen peroxide scavenging ability of extracts of $E$. monogynum was investigated according to the method developed [18] with slight modifications and performed in quintuplicate. A concentration of $43 \mathrm{mM}$ of hydrogen peroxide in phosphate buffer (1M, pH 7.4) was prepared and used for the study. Different concentration of sample (10$500 \mu \mathrm{g} / \mathrm{ml})$ was added to a hydrogen peroxide solution $(0.6 \mathrm{ml}$, $43 \mathrm{mM}$ ) and after $10 \mathrm{~min}$ the absorbance was measured at 230 $\mathrm{nm}$ against a blank prepared with phosphate buffer without hydrogen peroxide. Ascorbic acid served as a reference compound. The free radical scavenging activity was determined by assessing the \% inhibition using the following formula:

$\%$ inhibition $=($ Control- Test $) /$ control $\times 100$

\section{$\beta$-carotene bleaching assay}

The $\beta$-carotene bleaching assay was performed according to the method developed and published in the literature [19]. In this assay, $2 \mathrm{ml}$ of $\beta$-carotene (Conc. of $200 \mu \mathrm{g} / \mathrm{ml}$ in chloroform) was taken in a round bottom flask and mixed with $20 \mu \mathrm{l}$ linoleic acid and $200 \mu \mathrm{l}$ Tween 20 , mixed thoroughly and evaporated for $10 \mathrm{~min}$ at $40^{\circ} \mathrm{C}$ followed by the addition of $100 \mathrm{ml}$ of distilled water (HPLC grade). The mixture was subjected to the vortex and an aliquot of $5 \mathrm{ml}$ of the resulting emulsion was transferred into test tubes containing various concentrations $(10-500 \mu \mathrm{g} / \mathrm{ml})$ of E. monogynum extracts. The mixture was placed in a water bath at $50^{\circ} \mathrm{C}$ for $2 \mathrm{~h}$ and the absorbance was measured every $15 \mathrm{~min}$ at $470 \mathrm{~nm}$ using a UV-VIS spectrophotometer (Shimadzu UV1900). All experiments were performed in quintuplicate. The total antioxidant activity was calculated based on the following formula

Anti-oxidant activity $\%=1-\left(\mathrm{A}_{0}-\mathrm{A}_{\mathrm{t}}\right) /\left(\mathrm{A}_{0}{ }^{0}-\mathrm{A}_{0}{ }^{\mathrm{t}}\right)$

Where, $\mathrm{A}_{0}=$ Absorbance of control; $\mathrm{A}_{\mathrm{t}}=$ Absorbance of sample

\section{Nitric oxide scavenging activity}

Nitric oxide scavenging activity was determined by the use of Griess Illosvory reaction [20]. Sodium nitroprusside in phosphate buffered saline was mixed with different concentrations $(1-100 \mu \mathrm{g} / \mathrm{ml})$ of extracts and incubated at 30 ${ }^{\circ} \mathrm{C}$ for $2 \mathrm{hrs}$. The reaction mixture without the extracts served as the negative control while Gallic acid was used as a positive control. After the incubation, $0.5 \mathrm{ml}$ of Griess reagent $(1 \%$ sulfanilamide, $\quad 2 \% \mathrm{H}_{3} \mathrm{PO}_{4}$ and $0.1 \% \mathrm{~N}-(1$-naphthyl) ethylenediamine dihydrochloride) was added and the absorbance was measured at 550nm. Subsequently, I C50 values (the inhibitory concentration required to reduce $50 \%$ of the nitric oxide formation) was measured for all the extracts. All experiments were carried out in quintuplicate. 


\section{Indo Global Journal of Pharmaceutical Sciences, 2020; 10(4): 77-87}

\section{Xanthine oxidase inhibition Assay}

Xanthine oxidase inhibitory assay was carried out according to the method developed and published in the literature [21] and performed in quintuplicate. All the extracts were dissolved and diluted in the buffer at a final concentration of $200 \mu \mathrm{g} / \mathrm{ml}$ and then used the same was used to assess their inhibitory activity. The reaction mixture contained an aliquot of $80 \mathrm{mM}$ sodium pyrophosphate buffer $(\mathrm{pH}=8.5), 0.120 \mathrm{mM}$ xanthine, and 0.1 unit of XO. The absorption at $295 \mathrm{~nm}$, indicating the formation of uric acid at $25^{\circ} \mathrm{C}$, was monitored and the initial rate was calculated. A negative control (blank which has $0 \%$ $\mathrm{XO}$ inhibition activity) was prepared and this contained the assay mixture without the plant extracts. Allopurinol was used as a positive control in the assay mixture. Subsequently, $\mathrm{IC}_{50}$ values, the concentration at which $50 \%$ of the $\mathrm{XO}$ enzyme activity inhibited was determined. The XO inhibitory activity was expressed as the percentage inhibition of $\mathrm{XO}$ in the above-mentioned assay mixture system, calculated as follows:

$\%$ Inhibition $=\left(1-\frac{\text { Test Inclination }}{\text { Blank Inclination }}\right) \times 100$

Where, test inclination is the linear change in the absorbance per minute of the test material, and blank inclination is the linear change in the absorbance per minute of the blank.

\section{Anti-glycation activity}

The Anti-glycation assay was carried out according to [22] with slight modifications. Briefly, BSA $(1 \mathrm{mg} / \mathrm{mL})$ was incubated with $0.25 \mathrm{M}$ fructose and $0.25 \mathrm{M}$ glucose in $0.1 \mathrm{M}$ phosphate-buffered saline (PBS), $\mathrm{pH} 7.4$, in darkness at $50^{\circ} \mathrm{C}$ for 4 days. Before incubation, the solution of essential oils, extracts and reference standard, aminoguanidine was dissolved in 50\% DMSO was added to the mixture. The glycated BSA thus formed was determined using fluorescent intensity at 335 $\mathrm{nm}$ (excitation wave length) and $385 \mathrm{~nm}$ (emission wave length). All the experiments were performed in quintuplicate. Various concentrations of extracts ranging from 1- $100 \mu \mathrm{g} / \mathrm{ml}$ providing 50\% AGE inhibitions ( $\left.\mathrm{I}_{\mathrm{C} 50}\right)$ were calculated from the graph of inhibition percentage against the extract concentration.

The inhibition percentage of AGEs was determined using the following formula

$\%$ AGE $=\left(\mathrm{F}_{\text {control }}-\mathrm{F}_{\text {control blank }}\right) \times 100 /\left(\mathrm{F}_{\text {extract }}-\mathrm{F}_{\text {extract blank }}\right)$

Where,

$\left(\mathrm{F}_{\text {control }}-\mathrm{F}_{\text {control blank }}\right)$ is the difference between the fluorescent intensity of BSA incubated with or without glucose and fructose
( $\left.F_{\text {extract }}-F_{\text {extract blank }}\right)$ is the difference between the fluorescent intensity of BSA and sugars incubated with or without plant extracts.

\section{Statistical Analysis}

All the experiments were carried out in quintuplicate and the data were subjected to statistical analysis using Graphpad Prism Software and Sigma Plot software.

\section{RESULTS AND DISCUSSION}

The leaves and stems were subjected to solvent extractions using petroleum ether and ethanol and were screened for the various phytochemicals. The yield of extracts was $4.36 \%$ and $5.41 \%$ in leaves and $3.48 \%$ and $4.32 \%$ in stems respectively for petroleum ether and ethanol solvents. Both leaves and stems extracts showed the presence of terpenoids, sterols, tannins, alkaloids and flavonoids (Table-1). The chemical composition of essential oil extracts from leaves and stems of E. monogynum was determined by GC and GC-MS and presented (Table-2). It showed that hydro distillation of leaves yielded $0.24 \%$ essential oil (EO) on a fresh weight basis. The GC-MS and GC analysis using Retention indices (RI) revealed that a total of 35 compounds accounting to $88 \%$ in leaves and 37 compounds amounting to $75 \%$ in stems were identified (Table-1). The major components in leaf oil were limonene $(9.24 \%)$, geijerene (11.28\%), pregeijerene (4.28\%), isobornyl acetate $(5.32 \%)$, germacrene D (9.78\%) and farnesol (4.72\%) while stem oil was rich in limonene (6.18\%), trans- $\beta$-ocimene $(3.16 \%)$, geijerene $(7.82 \%)$, pregeijerene (7.87\%), Methyl Eugenol (4.27\%), isobornyl acetate (3.41\%), germacrene D (6.79\%) and Farnesol (3.97\%). A major portion of oxygenated fraction of the oil was comprised by alcohols i.e. $24.64 \%$ and $22.51 \%$ respectively in leaves and stems. Methyl eugenol, dihydrocarveol, borneol, isothujanol, isopulegol, nerolidol, spathulenol, $\beta$-bisabolol and farnesol were observed to be present in predominant percentages in the essential oil extracts of E. monogynum. The chemical class distribution and major compounds of the essential oil are presented in Table-3. The sesquiterpene hydrocarbons were found to be the major constituents accounting for $37.31 \%$ and $27.94 \%$ respectively in leaf and stem oils. Interestingly, the group of sesquiterpenes was found to be dominant in both the essential oils. Nevertheless, the oxygenated derivatives of monoterpenes and sesquiterpenes have also been noticed as minor constituents.

The total phenolics and flavonoids were estimated and presented in Table-4. The total phenolic content was found to be 36.23 and $34.47 \mathrm{mg}$ of gallic acid/gm respectively for leaf and stem oils, while the total flavonoids were found to be 
Indo Global Journal of Pharmaceutical Sciences, 2020; 10(4): 77-87

respectively 16.71 and $14.17 \mathrm{mg}$ of quercetin /gm for leaf and stem essential oil extracts.

Table-1: Phytochemical screening of leaves and stems of $E$. monogynum

\begin{tabular}{|c|c|c|c|}
\hline Parts used & $\begin{array}{l}\text { Secondary } \\
\text { metabolites }\end{array}$ & $\begin{array}{l}\text { EtOH } \\
\text { extracts }\end{array}$ & $\begin{array}{l}\text { Petroleum } \\
\text { ether } \\
\text { extracts }\end{array}$ \\
\hline \multirow{7}{*}{ Leaves } & Tannins & + & + \\
\hline & Flavonoids & + & - \\
\hline & Alkaloids & ++ & - \\
\hline & Terpenoids & ++ & + \\
\hline & Anthaquinones & - & - \\
\hline & Carbohydrates & + & - \\
\hline & Sterols & + & ++ \\
\hline \multirow{7}{*}{ Stems } & Tannins & + & + \\
\hline & Flavonoids & + & - \\
\hline & Alkaloids & ++ & - \\
\hline & Terpenoids & ++ & + \\
\hline & Anthaquinones & - & - \\
\hline & Carbohydrates & - & - \\
\hline & Sterols & - & + \\
\hline
\end{tabular}

Table-2: Chemical composition of essential oil from leaves and stems of $E$. monogynum

\begin{tabular}{|c|c|c|c|c|c|}
\hline \multirow{2}{*}{$\begin{array}{l}\text { S. } \\
\text { No } \\
\text {. }\end{array}$} & \multirow[t]{2}{*}{ Compound } & \multirow[t]{2}{*}{ RI } & \multicolumn{2}{|c|}{$\begin{array}{l}\% \\
\text { Composition }\end{array}$} & \multirow{2}{*}{$\begin{array}{l}\text { Method of } \\
\text { Identificatio } \\
\text { n }\end{array}$} \\
\hline & & & $\begin{array}{l}\text { Leave } \\
\mathrm{s}\end{array}$ & $\begin{array}{l}\text { Stem } \\
\mathrm{s}\end{array}$ & \\
\hline 1. & $\alpha$-pinene & 937 & 2.98 & 0.86 & $\mathrm{a}, \mathrm{b}, \mathrm{c}$ \\
\hline 2. & Sabinene & 977 & 2.06 & 1.14 & $\mathrm{a}, \mathrm{b}, \mathrm{c}$ \\
\hline 3. & $\beta$-pinene & 981 & 1.85 & 1.02 & $a, b, c$ \\
\hline 4. & Myrcene & 984 & 1.12 & 0.71 & $\mathrm{a}, \mathrm{b}, \mathrm{c}$ \\
\hline 5. & $\begin{array}{l}\alpha- \\
\text { phellendrene }\end{array}$ & $\begin{array}{l}100 \\
9\end{array}$ & 1.16 & 1.28 & $\mathrm{a}, \mathrm{b}, \mathrm{c}$ \\
\hline 6. & $\alpha$-terpinene & $\begin{array}{l}102 \\
0\end{array}$ & 1.08 & 1.77 & $\mathrm{a}, \mathrm{b}, \mathrm{c}$ \\
\hline 7. & Limonene & $\begin{array}{l}102 \\
4\end{array}$ & 9.24 & 6.18 & $\mathrm{a}, \mathrm{b}, \mathrm{c}$ \\
\hline
\end{tabular}

\begin{tabular}{|c|c|c|c|c|c|}
\hline 8. & Cis- $\beta$-ocimene & $\begin{array}{l}103 \\
5\end{array}$ & 1.17 & 0.96 & $\mathrm{a}, \mathrm{b}, \mathrm{c}$ \\
\hline 9. & $\begin{array}{l}\text { Trans- } \beta- \\
\text { ocimene }\end{array}$ & $\begin{array}{l}104 \\
0\end{array}$ & 1.97 & 3.16 & $\mathrm{a}, \mathrm{b}, \mathrm{c}$ \\
\hline 10. & Linalool & $\begin{array}{l}108 \\
5\end{array}$ & 0.98 & 0.57 & $\mathrm{a}, \mathrm{b}, \mathrm{c}$ \\
\hline 11. & Isofenchol & $\begin{array}{l}110 \\
1\end{array}$ & 2.16 & 1.24 & $\mathrm{a}, \mathrm{b}, \mathrm{c}$ \\
\hline 12. & $\begin{array}{l}\text { Sabinene } \\
\text { hydrate }\end{array}$ & $\begin{array}{l}111 \\
6\end{array}$ & 0.89 & 0.72 & $\mathrm{a}, \mathrm{b}, \mathrm{c}$ \\
\hline 13. & Geijerene & $\begin{array}{l}114 \\
3\end{array}$ & 11.28 & 7.82 & $\mathrm{a}, \mathrm{b}, \mathrm{c}$ \\
\hline 14. & Isopulegol & $\begin{array}{l}114 \\
6\end{array}$ & 1.48 & 1.02 & $\mathrm{a}, \mathrm{b}, \mathrm{c}$ \\
\hline 15. & Isothujanol & $\begin{array}{l}115 \\
7\end{array}$ & 2.36 & 1.47 & $\mathrm{a}, \mathrm{b}, \mathrm{c}$ \\
\hline 16. & $\begin{array}{l}\text { Terpinene-4- } \\
\text { ol }\end{array}$ & $\begin{array}{l}116 \\
6\end{array}$ & 0 & 0.68 & $\mathrm{a}, \mathrm{b}, \mathrm{c}$ \\
\hline 17. & Borneol & $\begin{array}{l}118 \\
0\end{array}$ & 2.11 & 1.04 & $\mathrm{a}, \mathrm{b}, \mathrm{c}$ \\
\hline 18 & Decanal & $\begin{array}{l}119 \\
2\end{array}$ & $\operatorname{Tr}$ & 2.34 & $\mathrm{a}, \mathrm{b}, \mathrm{c}$ \\
\hline 19. & $\begin{array}{l}\text { Dihydrocarve } \\
\text { ol }\end{array}$ & $\begin{array}{l}119 \\
5\end{array}$ & 2.89 & 1.73 & $\mathrm{a}, \mathrm{b}, \mathrm{c}$ \\
\hline 20. & Geraniol & $\begin{array}{l}124 \\
0\end{array}$ & 0 & 0.78 & $a, b, c$ \\
\hline 21. & $\begin{array}{l}\text { Isobornyl } \\
\text { acetate }\end{array}$ & $\begin{array}{l}127 \\
1\end{array}$ & 5.32 & 3.41 & $\mathrm{a}, \mathrm{b}, \mathrm{c}$ \\
\hline 22. & Pregeijerene & $\begin{array}{l}128 \\
5\end{array}$ & 4.28 & 7.87 & $\mathrm{a}, \mathrm{b}, \mathrm{c}$ \\
\hline 23. & Delta elemene & $\begin{array}{l}133 \\
7\end{array}$ & 0.67 & 0.58 & $\mathrm{a}, \mathrm{b}, \mathrm{c}$ \\
\hline 24. & $\begin{array}{l}\text { Methyl } \\
\text { cinnamte }\end{array}$ & $\begin{array}{l}134 \\
2\end{array}$ & 0.28 & 1.29 & $\mathrm{a}, \mathrm{b}, \mathrm{c}$ \\
\hline 25. & $\begin{array}{l}\text { Geranyl } \\
\text { acetate }\end{array}$ & $\begin{array}{l}137 \\
0\end{array}$ & 0.96 & 1.36 & $\mathrm{a}, \mathrm{b}, \mathrm{c}$ \\
\hline 26. & $\beta$-Bourbonene & $\begin{array}{l}138 \\
6\end{array}$ & 1.44 & 0.16 & $\mathrm{a}, \mathrm{b}, \mathrm{c}$ \\
\hline 27. & $\beta$-Elemene & $\begin{array}{l}138 \\
9\end{array}$ & 0.69 & 1.23 & $\mathrm{a}, \mathrm{b}, \mathrm{c}$ \\
\hline 28. & $\begin{array}{l}\text { Methyl } \\
\text { eugenol }\end{array}$ & $\begin{array}{l}140 \\
3\end{array}$ & 1.07 & 4.27 & $\mathrm{a}, \mathrm{b}, \mathrm{c}$ \\
\hline 29. & $\begin{array}{l}\beta- \\
\text { caryophyllene }\end{array}$ & $\begin{array}{l}142 \\
1\end{array}$ & 2.16 & 1.96 & $\mathrm{a}, \mathrm{b}, \mathrm{c}$ \\
\hline 30. & $\alpha$-humulene & $\begin{array}{l}144 \\
6\end{array}$ & 1.27 & 1.32 & $\mathrm{a}, \mathrm{b}, \mathrm{c}$ \\
\hline 31. & Germacrene D & $\begin{array}{l}148 \\
0\end{array}$ & 9.78 & 6.79 & $\mathrm{a}, \mathrm{b}, \mathrm{c}$ \\
\hline 32. & D-cadinene & $\begin{array}{l}153 \\
6\end{array}$ & 0.42 & 2.21 & $\mathrm{a}, \mathrm{b}, \mathrm{c}$ \\
\hline
\end{tabular}


Indo Global Journal of Pharmaceutical Sciences, 2020; 10(4): 77-87

\begin{tabular}{|c|c|c|c|c|c|}
\hline 33. & Nerolidol & $\begin{array}{l}154 \\
4\end{array}$ & 2.86 & 1.98 & $\mathrm{a}, \mathrm{b}, \mathrm{c}$ \\
\hline 34. & Spathulenol & $\begin{array}{l}156 \\
4\end{array}$ & 2.19 & 1.67 & $\mathrm{a}, \mathrm{b}, \mathrm{c}$ \\
\hline 35. & $\begin{array}{l}\text { Caryophyllene } \\
\text { oxide }\end{array}$ & $\begin{array}{l}157 \\
4\end{array}$ & 0.64 & 1.29 & $\mathrm{a}, \mathrm{b}, \mathrm{c}$ \\
\hline 36. & $\tau$-cadinol & $\begin{array}{l}164 \\
2\end{array}$ & 0.98 & 0.52 & $\mathrm{a}, \mathrm{b}, \mathrm{c}$ \\
\hline 37. & $\beta$-bisabolol & $\begin{array}{l}167 \\
2\end{array}$ & 0.84 & 1.57 & $\mathrm{a}, \mathrm{b}, \mathrm{c}$ \\
\hline 38. & Farnesol & $\begin{array}{l}169 \\
9\end{array}$ & 4.72 & 3.97 & $\mathrm{a}, \mathrm{b}, \mathrm{c}$ \\
\hline 39. & $\begin{array}{l}\text { Farnesyl } \\
\text { acetate }\end{array}$ & $\begin{array}{l}179 \\
0\end{array}$ & 0.78 & 0.35 & $\mathrm{a}, \mathrm{b}, \mathrm{c}$ \\
\hline
\end{tabular}

$\mathrm{a}$ - Retention time; $\mathrm{b}$ - Retention indices; $\mathrm{c}$ - Mass spectra

Table-3: Chemical class distribution and major components in the essential oil from leaves and stems of $E$.

monogynum

\begin{tabular}{|c|c|c|c|c|c|}
\hline $\begin{array}{l}\text { Part } \\
\text { of } \\
\text { the } \\
\text { Plan } \\
t\end{array}$ & $\begin{array}{l}\text { Compoun } \\
\text { d class }\end{array}$ & $\begin{array}{l}\text { Area } \\
\text { perce } \\
\text { nt }\end{array}$ & $\begin{array}{l}\text { No. of } \\
\text { compou } \\
\text { nds }\end{array}$ & $\begin{array}{l}\text { Major } \\
\text { compound }\end{array}$ & $\begin{array}{l}\text { Area } \\
\text { perce } \\
\text { nt }\end{array}$ \\
\hline \multirow{4}{*}{$\begin{array}{l}\text { Leav } \\
\text { es }\end{array}$} & $\begin{array}{l}\text { Monoterpe } \\
\text { ne } \\
\text { hydrocarb } \\
\text { ons }\end{array}$ & 22.63 & 9 & Limonene & 9.24 \\
\hline & $\begin{array}{l}\text { Oxygenate } \\
\mathrm{d} \\
\text { monoterpe } \\
\text { nes }\end{array}$ & 15.18 & 11 & $\begin{array}{l}\text { Dihydrocar } \\
\text { veol }\end{array}$ & 2.89 \\
\hline & $\begin{array}{l}\text { Sesquiterp } \\
\text { enes }\end{array}$ & 37.31 & 10 & Geijerene & 11.28 \\
\hline & $\begin{array}{l}\text { Oxygenate } \\
\mathrm{d} \\
\text { sesquiterp } \\
\text { enes }\end{array}$ & 13.01 & 7 & Farnesol & 4.72 \\
\hline \multirow[t]{4}{*}{$\begin{array}{l}\text { Stem } \\
\text { s }\end{array}$} & $\begin{array}{l}\text { Monoterpe } \\
\text { ne } \\
\text { hydrocarb } \\
\text { ons }\end{array}$ & 17.08 & 9 & Limonene & 6.18 \\
\hline & $\begin{array}{l}\text { Oxygenate } \\
\mathrm{d} \\
\text { monoterpe } \\
\text { nes }\end{array}$ & 18.51 & 13 & $\begin{array}{l}\text { Methyl } \\
\text { Eugenol }\end{array}$ & 4.27 \\
\hline & $\begin{array}{l}\text { Sesquiterp } \\
\text { enes }\end{array}$ & 27.94 & 10 & $\begin{array}{l}\text { Pregeijeren } \\
\mathrm{e}\end{array}$ & 7.87 \\
\hline & $\begin{array}{l}\text { Oxygenate } \\
\text { d }\end{array}$ & 11.35 & 7 & Farnesol & 3.97 \\
\hline
\end{tabular}

sesquiterp

enes

Table-4: Quantitative determination of the total phenolic and flavonoid content

\begin{tabular}{|c|c|c|}
\hline Extract & $\begin{array}{l}\text { Total Polyphenol } \\
\text { content } \\
(\mathrm{mg} \text { of gallic } \\
\text { acid/gm) }\end{array}$ & $\begin{array}{l}\text { Total flavonoid } \\
\text { content } \\
\text { (mg of quercetin } \\
\text { /gm) }\end{array}$ \\
\hline Ethanol extract & $26.71 \pm 0.87$ & $10.51 \pm 0.42$ \\
\hline $\begin{array}{l}\text { Petroleum ether } \\
\text { extract }\end{array}$ & $20.13 \pm 1.05$ & $9.17 \pm 0.63$ \\
\hline Leaf essential oil & $36.23 \pm 0.89$ & $16.71 \pm 0.97$ \\
\hline Stem essential oil & $34.47 \pm 0.96$ & $14.17 \pm 1.01$ \\
\hline
\end{tabular}

The antioxidant efficacy of essential oil and extracts were evaluated by standard methods and the results are depicted in Table 5-7. Among all the extracts tested for DPPH scavenging activity, leaf essential oil at $100 \mu \mathrm{g} / \mathrm{ml}$ showed maximum activity of $90.33 \%$ followed by stem essential oil (79.84\%), ethanol extract (61.64\%) and pet ether extract (54.72\%), while, ascorbic acid, the standard compound showed $100 \%$ activity at $80 \mu \mathrm{g} / \mathrm{ml}$. Further the essential oil from leaves showed maximum $\mathrm{H}_{2} \mathrm{O}_{2}$ scavenging activity of $90 \%$ at $100 \mu \mathrm{g} / \mathrm{ml}$, while, the reference standard ascorbic acid exhibited $100 \%$ activity at $80 \mu \mathrm{g} / \mathrm{ml}$ for the assay. These results indicate that essential oil from leaves has antioxidant potential comparable with that of ascorbic acid. Interestingly, the $\beta$-carotene bleaching assay results depicted in Table-7 demonstrated a higher antioxidant activity of leaf essential oil with $\mathrm{IC}_{50}$ of $54.72 \mu \mathrm{g} / \mathrm{ml}$ followed by stem oil, ethanol and pet ether extracts. Nitric Oxide (NO) scavenging assay based on the scavenging ability of the essential oil and extracts was evaluated in a dose-dependent manner using Gallic acid as a positive control sample. As evident from the table-8, among all the samples tested, leaf oil exhibited potent NO scavenging activity with $\mathrm{IC}_{50}$ of $58.64 \mu \mathrm{g} / \mathrm{ml}$. While, the $\mathrm{IC}_{50}$ of stem oil, ethanol and pet ether extracts was found to be 66.23, 75.28 and $84.11 \mu \mathrm{g} / \mathrm{ml}$ respectively.

It is well known that phenols and terpenes are very important constituents in plants and which contribute to the antioxidant potential of various botanicals [23]. Phytochemicals, exclusively plant essential oils are known to possess primary antioxidant activity as they can react with active oxygen radicals, such as hydroxyl radicals, superoxide anion radicals and lipid peroxy radicals and inhibit lipid oxidation at an early 


\section{Indo Global Journal of Pharmaceutical Sciences, 2020; 10(4): 77-87}

stage. It has also been reported that the increase in the phenolic content can be used as a biomarker for screening of air pollutants [24]. It has been well established that flavonoids are antioxidants compounds and recognized as valuable nutraceuticals for neutralizing free radical stress. The antioxidant properties of plant extracts can often be attributed to the presence of a substantial amount of terpenes and phenols. In the present study, however, the maximum activity exhibited by E. monogynum extracts can be correlated to the presence of more amounts of phenols and terpenes and might be employed in the treatment of stress and other related disorders.

In the present study, essential oils and extracts were evaluated as potential $\mathrm{XO}$ inhibitors and compared favourably with the positive control sample, Allopurinol and the results are summarized in Table 9. Among all the extracts tested, the leaf and stem essential oils showed maximum Xanthine oxidase inhibition activity with an $\mathrm{IC}_{50}$ of 42.63 and $53.74 \mu \mathrm{g} / \mathrm{ml}$ respectively. While the standard compound, Allopurinol showed an $\mathrm{IC}_{50}$ of $10.28 \mu \mathrm{g} / \mathrm{ml}$.

The essential oils, phenols and flavonoids have been reported to possess Xanthine oxidase inhibitory effects [25-26]. Moreover, the results obtained are in agreement with the previously published reports showing remarkable xanthine oxidase inhibitory activities of essential oils and extracts of $E$. monogynum. At present, Allopurinol is the drug of choice for gout disease however, due to its prolonged usage, it is presenting various side effects. Therefore, as a part of screening program of medicinal plants of South India and based on ethnobotanical information, E. monogynum plant has been selected for evaluation of xanthine oxidase inhibitor activity, where, both leaves and stems oils exhibited marked inhibitory activity comparable to allopurinol.

The ability of E. monogynum extracts to inhibit AGE formation was evaluated using the anti-glycation assay, in which bovine serum albumin and glucose and fructose served as the model protein and glycating agents respectively. The formation of AGEs was assessed by monitoring the production of fluorescent products at $335 \mathrm{~nm}$ and $385 \mathrm{~nm}$, respectively and the results were depicted in table-10. It was evident from the table that all the tested extracts inhibited AGE formation in a dose-dependent manner. Leaf and stem essential oils presented the higher inhibitory effect of more than $90 \%$ inhibition of AGE formation at a concentration of $100 \mu \mathrm{g} / \mathrm{ml}$ and with an $\mathrm{IC}_{50}$ values of 32.77 and $44.46 \mu \mathrm{g} / \mathrm{ml}$ respectively. The percentage inhibition of NO scavenging, Xanthine oxidase inhibition and Anti-glycation activities with concerning concentration were also evaluated and presented in
Fig. 1-3. The degree of activities was evaluated for all the extracts at a concentration ranging from $1-100 \mu \mathrm{g} / \mathrm{ml}$. The significant observation was that with an increase in the concentration of all the extracts, there was a subtle but noticeable increase in percentage inhibition.

The effect of essential oils and extracts on BSA glycation was determined by the inhibition of fructosamine formation and it was found that different extracts exhibited a varied degree of potential to inhibit initial stages of glycation reaction. The hyperglycemic state that is commonly seen in Diabetes mellitus patients is reported to be associated with cardiovascular complications [27] and these evidences implicate the formation and subsequent effects of AGEs as a contributing cause for such a complication. Further, it has been reported recently that there is increased oxidative damage in the vicinity of glycated histone residues [27-28]. Advanced glycation end products (AGEs) have been involved in the pathogenesis of diabetes and aging-related complications and therefore, inhibition of glycation should have a broad and beneficial effect in the treatment. However, several traditionally used herbal medicines and essential oils have been shown to possess in vitro anti-glycation effects due to the presence of terpenes and phenols [29]. The oils under investigation demonstrated excellent ant-glycation activity by inhibiting more than $90 \%$ of AGEs formation which can be attributed to the presence of higher concentration sesquiterpenes. However, the synergistic effect of all the components in the oil cannot be neglected.

Table-5: DPPH scavenging activity of extracts of $E$. monogynum

\begin{tabular}{|c|c|c|c|c|c|}
\hline \multirow{2}{*}{$\begin{array}{l}\text { Concentration } \\
(\mu \mathrm{g} / \mathrm{ml})\end{array}$} & \multicolumn{5}{|c|}{ DPPH radical scavenging activity (\%) } \\
\hline & $\begin{array}{l}\text { Pet } \\
\text { ether } \\
\text { extract }\end{array}$ & $\begin{array}{l}\text { Ethanol } \\
\text { Extract }\end{array}$ & SO & LO & $\begin{array}{l}\text { Ascorbic } \\
\text { acid }\end{array}$ \\
\hline 10 & $\begin{array}{l}5.64 \pm \\
0.51\end{array}$ & $\begin{array}{cc}8.89 & \pm \\
0.61 & \end{array}$ & $\begin{array}{l}11.22 \\
\pm \\
0.68\end{array}$ & $\begin{array}{r}15.68 \\
\pm 0.78\end{array}$ & $25.23 \pm 0.77$ \\
\hline 20 & $\begin{array}{r}11.97 \\
\pm 0.74\end{array}$ & $\begin{array}{l}17.32 \pm \\
0.92\end{array}$ & $\begin{array}{l}23.51 \\
\pm \\
0.87\end{array}$ & $\begin{array}{r}28.19 \\
\pm 0.88\end{array}$ & $\begin{array}{ll}35.59 & \pm \\
0.98 & \end{array}$ \\
\hline 40 & $\begin{array}{r}23.08 \\
\pm 1.06\end{array}$ & $\begin{array}{l}27.81 \pm \\
1.12\end{array}$ & $\begin{array}{l}33.08 \\
\pm \\
1.05\end{array}$ & $\begin{array}{r}41.27 \\
\pm 1.01\end{array}$ & $\begin{array}{r}50.27 \\
\pm 1.21\end{array}$ \\
\hline 60 & $\begin{array}{r}32.17 \\
\pm 1.22\end{array}$ & $\begin{array}{l}41.72 \pm \\
1.16\end{array}$ & $\begin{array}{l}47.85 \\
\pm \\
1.22\end{array}$ & $\begin{array}{r}59.74 \\
\pm 1.26\end{array}$ & $\begin{array}{l}81.98 \\
1.37\end{array}$ \\
\hline 80 & $\begin{array}{r}41.39 \\
\pm 1.99\end{array}$ & $\begin{array}{l}48.16 \pm \\
1.68\end{array}$ & $\begin{array}{l}66.73 \\
\pm \\
2.06\end{array}$ & $\begin{array}{r}73.19 \\
\pm 2.17\end{array}$ & 100 \\
\hline $3^{100}$ & $\begin{array}{r}54.72 \\
\pm 2.25\end{array}$ & $\begin{array}{l}61.64 \pm \\
1.97\end{array}$ & $\begin{array}{l}79.84 \\
\pm \\
2.18\end{array}$ & $\begin{array}{l}90.33 \pm \\
2.21\end{array}$ & 100 \\
\hline
\end{tabular}




\section{Indo Global Journal of Pharmaceutical Sciences, 2020; 10(4): 77-87}

Test extracts: significant from normal control, $\mathrm{P}<0.05$

Mean \pm S.E.M $=$ Mean values \pm Standard error of means of five experiments

Table-6: $\mathrm{H}_{2} \mathrm{O}_{2}$ free radical scavenging activity of essential oil extracts of $E$. monogynum

Concentrati Hydrogen peroxide free radical scavenging on activity (\%)

$(\mu \mathrm{g} / \mathrm{ml})$

\begin{tabular}{|c|c|c|c|c|c|}
\hline & $\begin{array}{l}\text { Pet } \\
\text { ether } \\
\text { extra } \\
\text { ct }\end{array}$ & $\begin{array}{l}\text { Ethan } \\
\text { ol } \\
\text { extrac } \\
\text { t }\end{array}$ & SO & LO & $\begin{array}{l}\text { Ascorbic } \\
\text { acid }\end{array}$ \\
\hline 10 & $\begin{array}{l}4.25 \\
\pm 0.51\end{array}$ & $\begin{array}{l}9.09 \pm \\
0.32\end{array}$ & $\begin{array}{l}12.3 \\
4 \quad \pm \\
0.69\end{array}$ & $\begin{array}{r}16.42 \\
\pm 0.76\end{array}$ & $\begin{array}{l}28.15 \pm 0 \text {. } \\
74\end{array}$ \\
\hline 20 & $\begin{array}{c}8.16 \\
\pm 0.75\end{array}$ & $\begin{array}{r}19.84 \\
\pm 0.92\end{array}$ & $\begin{array}{l}24.6 \\
5 \quad \pm \\
0.93\end{array}$ & $\begin{array}{r}29.36 \\
\pm 0.91\end{array}$ & $\begin{array}{l}40.21 \quad \pm \\
0.99\end{array}$ \\
\hline 40 & $\begin{array}{r}16.19 \\
\pm 1.02\end{array}$ & $\begin{array}{r}24.66 \\
\pm 1.41\end{array}$ & $\begin{array}{l}30.4 \\
3 \quad \pm \\
1.22\end{array}$ & $\begin{array}{r}41.68 \\
\pm 1.24\end{array}$ & $\begin{array}{c}56.52 \\
\pm 1.12\end{array}$ \\
\hline 60 & $\begin{array}{r}28.46 \\
\pm 1.48\end{array}$ & $\begin{array}{r}41.37 \\
\pm 1.37\end{array}$ & $\begin{array}{l}49.0 \\
9 \quad \pm \\
1.79\end{array}$ & $\begin{array}{r}65.83 \\
\pm 1.29\end{array}$ & $\begin{array}{l}85.63 \quad \pm \\
1.46\end{array}$ \\
\hline 80 & $\begin{array}{r}34.28 \\
\pm 1.71\end{array}$ & $\begin{array}{r}53.33 \\
\pm 1.69\end{array}$ & $\begin{array}{l}63.2 \\
6 \quad \pm \\
2.37\end{array}$ & $\begin{array}{r}78.17 \\
\pm 1.33\end{array}$ & 100 \\
\hline 100 & $\begin{array}{l}50.78 \\
\pm 2.29\end{array}$ & $\begin{array}{r}63.06 \\
\pm 2.26\end{array}$ & $\begin{array}{l}75.3 \\
7 \quad \pm \\
2.41\end{array}$ & $\begin{array}{r}90.02 \\
\pm 2.38\end{array}$ & 100 \\
\hline
\end{tabular}

Test extracts: significant from normal control, $\mathrm{P}<0.05$

Mean \pm S.E.M $=$ Mean values \pm Standard error of means of five experiments

Table-7: $\beta$-carotene bleaching assay of extracts of $E$. monogynum

\begin{tabular}{|l|l|ll|}
\hline $\begin{array}{l}\text { Sl. } \\
\text { No. }\end{array}$ & Sample/Extract & \multicolumn{3}{|l|}{$\mathbf{C}_{\mathbf{5 0}}(\boldsymbol{\mu} \mathbf{g} / \mathbf{m l})$} \\
\hline 1. & Pet ether extract & $\begin{array}{l}96.63 \quad \pm \quad 2.27 \\
105.205)\end{array}$ \\
\hline 2. & Ethanol extract & $81.73 \pm 1.66(69.628-93.434)$ & - \\
\hline 3. & SO & $62.36 \pm 1.48(53.189-71.344)$ \\
\hline 4. & LO & $54.72 \pm 1.34(47.118-62.271)$ \\
\hline
\end{tabular}

Test extracts: significant from normal control, $\mathrm{P}<0.05$

All values are expressed as Mean $\pm \mathrm{SE}$;

The numbers in parenthesis represents $95 \%$ confidence limits
Table-8: NO scavenging activity of essential oil and extracts from $E$. monogynum

\begin{tabular}{|l|l|l|l|}
\hline S. No. & Sample/Extract & IC $\mathbf{5 0}(\boldsymbol{\mu g} / \mathbf{m l})$ & $\begin{array}{l}\text { Relative } \\
\text { Potency }\end{array}$ \\
\hline 1. & $\begin{array}{l}\text { Petroleum ether } \\
\text { extract }\end{array}$ & $\begin{array}{l}84.11 \pm 1.28 \\
(49.198-70.232)\end{array}$ & 0.316 \\
\hline 2. & Ethanol extract & $\begin{array}{l}75.28 \pm 1.57 \\
(39.183-53.412)\end{array}$ & 0.353 \\
\hline 3. & SO & $\begin{array}{l}66.23 \pm 1.37 \\
(26.721-42.328)\end{array}$ & 0.401 \\
\hline 4. & LO & $\begin{array}{l}58.64 \pm 1.51 \\
(28.221-46.237)\end{array}$ & 0.453 \\
\hline 5. & Gallic acid & $\begin{array}{l}26.61 \pm 1.15 \\
(20.172-30.244)\end{array}$ & 1 \\
\hline & &
\end{tabular}

Test extracts: significant from normal control, $\mathrm{P}<0.05$ All values are expressed as Mean $\pm \mathrm{SE}$; Relative potency $=$ $\mathrm{IC}_{50}$ standard/IC $\mathrm{I}_{50}$ sample;

The numbers in parenthesis represents $95 \%$ confidence limits

Figure-1: Percentage inhibition of NO scavenging activity with increase in concentration of extracts and essential oil

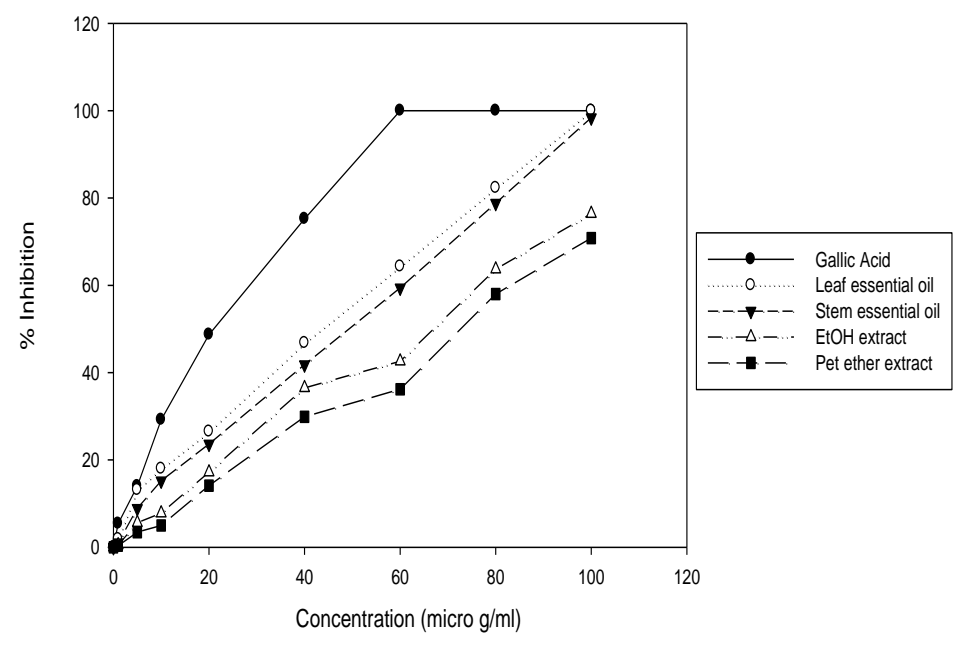


Indo Global Journal of Pharmaceutical Sciences, 2020; 10(4): 77-87

Table-9: Xanthine oxidase inhibitory potential of essential oil and extracts from $E$. monogynum

\begin{tabular}{|c|c|c|c|}
\hline Compound & $\mathrm{IC}_{50}(\mu \mathrm{g} / \mathrm{ml})$ & $\mathrm{IC}_{90}(\mu \mathrm{g} / \mathrm{ml})$ & $\begin{array}{l}\text { Relative } \\
\text { Potency }\end{array}$ \\
\hline $\begin{array}{l}\text { Petroleum } \\
\text { ether } \\
\text { extract }\end{array}$ & $\begin{array}{l}77.52 \\
(46.499-69.045)\end{array}$ & $\begin{array}{l}129.03 \\
(80.533 \\
99.068)\end{array}$ & 0.132 \\
\hline $\begin{array}{l}\text { Ethanol } \\
\text { extract }\end{array}$ & $\begin{array}{l}61.46 \\
(32.281-51.402)\end{array}$ & $\begin{array}{l}101.64 \\
(58.457 \\
81.314)\end{array}$ & 0.167 \\
\hline SO & $\begin{array}{l}53.74 \\
(29.228-45.417)\end{array}$ & $\begin{array}{l}92.53 \\
(51.108 \\
72.245)\end{array}$ & 0.191 \\
\hline LO & $\begin{array}{l}42.63 \\
(31.627-52.608)\end{array}$ & $\begin{array}{l}78.06 \\
(57.118 \\
77.219)\end{array}$ & 0.241 \\
\hline Allopurinol & $\begin{array}{l}10.28 \\
(5.621-15.893)\end{array}$ & $\begin{array}{l}18.44 \\
(12.245 \\
30.557)\end{array}$ & 1 \\
\hline
\end{tabular}

Test extracts: significant from normal control, $\mathrm{P}<0.05$ All values are expressed as Mean $\pm \mathrm{SE}$; Relative potency $=$ $\mathrm{IC}_{50}$ standard/IC $\mathrm{C}_{50}$ sample;

The numbers in parenthesis represents $95 \%$ confidence limits

Figure-2: Percentage inhibition of xanthine oxidase at varying concentrations of allopurinol, extracts and essential oils

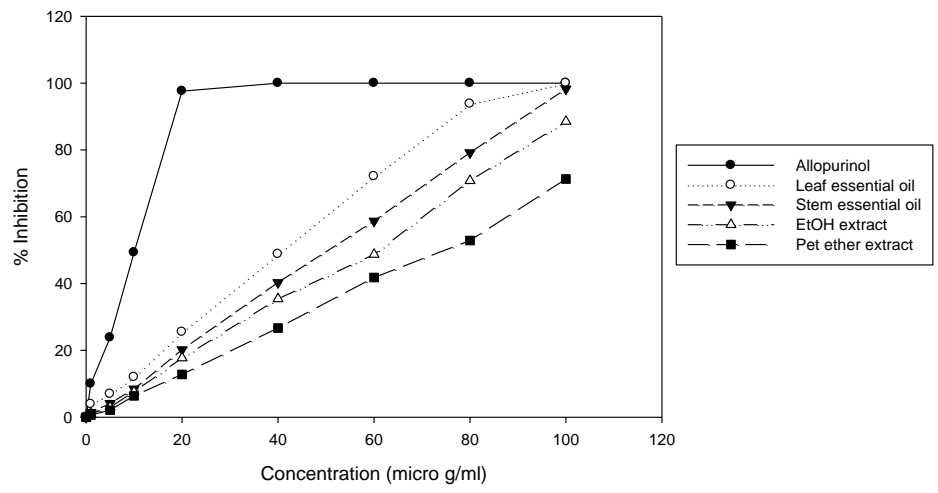

Table-10: Anti-glycation activity of essential oil and extracts from $E$. monogynum

\begin{tabular}{|c|c|c|c|}
\hline Compound & $\mathrm{IC}_{50}(\mu \mathrm{g} / \mathrm{ml})$ & $\begin{array}{l}\mathrm{IC}_{90} \\
(\mu \mathrm{g} / \mathrm{ml})\end{array}$ & $\begin{array}{l}\text { Relative } \\
\text { Potency }\end{array}$ \\
\hline $\begin{array}{l}\text { Petroleum ether } \\
\text { extract }\end{array}$ & $\begin{array}{l}81.29 \\
(76.991 \\
89.407)\end{array}$ & $\begin{array}{l}137.36 \\
(125.826- \\
145.389)\end{array}$ & 0.261 \\
\hline
\end{tabular}

\begin{tabular}{|c|c|c|c|c|c|}
\hline Ethanol extract & $\begin{array}{l}57.72 \\
(49.812 \\
65.245)\end{array}$ & - & $\begin{array}{l}96.26 \\
(88.171 \\
103.197)\end{array}$ & - & 0.367 \\
\hline SO & $\begin{array}{l}44.46 \\
(39.206 \\
49.713)\end{array}$ & - & $\begin{array}{l}79.87 \\
(72.064 \\
85.419)\end{array}$ & - & 0.477 \\
\hline LO & $\begin{array}{l}32.77 \\
(27.761 \\
37.083)\end{array}$ & - & $\begin{array}{l}68.69 \\
(62.128 \\
74.901)\end{array}$ & - & 0.647 \\
\hline Aminoguanidine & $\begin{array}{l}21.23 \\
(18.231 \\
25.334)\end{array}$ & - & $\begin{array}{l}58.36 \\
(54.514 \\
64.712)\end{array}$ & - & 1 \\
\hline
\end{tabular}

Test extracts: significant from normal control, $\mathrm{P}<0.05$ All values are expressed as Mean $\pm \mathrm{SE}$;

Relative potency $=\mathrm{IC}_{50}$ standard/IC $\mathrm{I}_{50}$ sample;

The numbers in parenthesis represents $95 \%$ confidence limits

Figure-3: Anti-glycation activity at varying concentrations of Aminoguanidine, extracts and essential oils

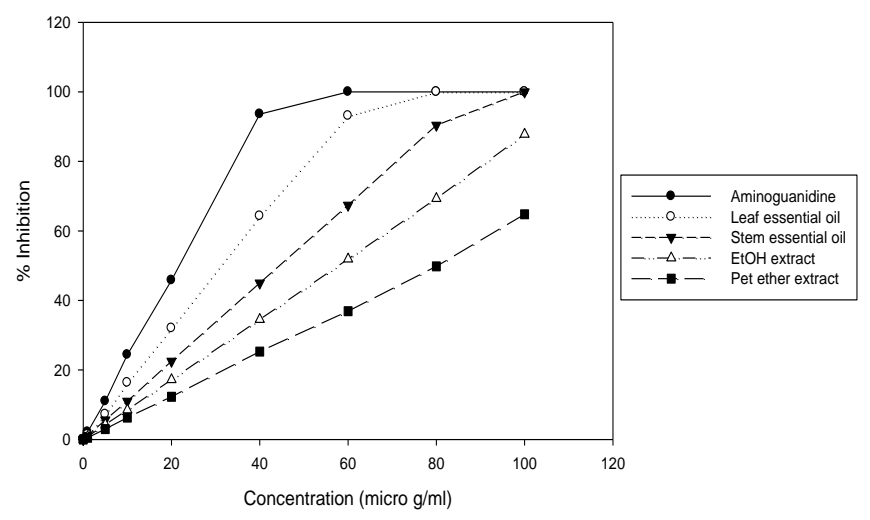

\section{CONCLUSION}

The results obtained are remarkable showing maximum antioxidant and anti-glycation activities of essential oil from leaves and stems of E. monogynum. Moreover, all the extracts showed excellent xanthine oxidase inhibitory activity and further studies might help to use this plant as a marker for standardization of herbal products or prototypes to develop more efficacious drugs with fewer side effects and might be useful in preventing or slowing the progress of gout and related disorders. Further work is underway to identify the active phytoconstituents in the oils and extracts wherein, the information procured not only suggests that the plant under investigation can be explored as a viable, better alternative source of natural antioxidant and anti-glycating agent but also help to develop promising lead products which could be useful for various pharmaceutical industries. 
Indo Global Journal of Pharmaceutical Sciences, 2020; 10(4): 77-87

\section{ACKNOWLEDGEMENT}

The authors are indebted to the Principal, Aurora's Degree \& PG College, Hyderabad for providing necessary facilities to carry out the work. One of the authors, Bindu G is highly grateful to the Director, R\&D Centre, Bharathiar University, Coimbatore for providing opportunity to pursue research in the field of Biochemistry.

\section{CONFLICTS OF INTEREST}

The authors declare that there is no conflict of interest regarding the publication of this paper.

\section{DATA AVAILABILITY}

Not declared.

\section{FUNDING SOURCE}

Not declared

\section{REFERENCES}

[1]. Halliwell, B., Gutteridge, J. M. Oxygen toxicity, oxygen radicals, transition metals and disease. Biochem J., 1984; 219 (1): 1 14.

[2]. Yu, B. P. Cellular defenses against damage from reactive oxygen species. Physiol. Rev., 1994; 74 (1): 139 - 162

[3]. Ames, B. N., Shigenaga, M. K., Hagen, T. M. Oxidants, antioxidants, and the degenerative diseases of aging. Proc Natl Acad Sci USA., 1993; 90(17): 7915-7922.

[4]. Joseph, J.A., Hale, B.S., Denisova, N.A., Bielinski, D., Martin, A., McEwen, J.J., Bickford, P. C. Reversals of age-related declines in neuronal signal transduction, cognitive, and motor behavioral deficits with blueberry, spinach, or strawberry dietary supplementation. J. Neuro Sci., 1999; 19 (18): 8114 - 21.

[5]. Ghadermazi, R., Khoshjou, F., Hossinizijoud, S.M., Behrooj, H., Kheiripour, N., Ganji, M. Hepatoprotective effect of tempol on oxidative toxic stress in STZ-induced diabetic rats. Toxin Rev., 2017; $37(1): 1-5$

[6]. Bizzo, H. R., Hovell, A.M.C., Rezende, C.M. Essential oils in Brazil: general aspects, development and perspectives. Quim Nova., 2009; 32 (3): 588-594.

[7]. Ramalho, V. C., Jorge, N. Anti-oxidants used in oils, fats and fatty foods. Quim Nova., 2006; 29(4): 755 - 760.

[8]. De Oliveira, A. C., Valentine, I. B., Goulart, M. O. F. Natural vegetable sources of Anti-oxidants. Quim Nova., 2009; 32 (3): 689 702.

[9]. Yunes, R. A., Cechimelson, V. Essential oils: importance and therapeutic Perspectives, ${ }^{\text {nd }}$ Ed.; Itajaí: University of Vale do Itajaí, pp.219-256., 2009.

[10]. Alagesaboopathi, C. Phytochemical screening and antibacterial potential of Couroupita guianensis aubl and Erythroxylum monogynum roxb. Int. J. Curr. Res., 2013; $\quad$ 5(8):2068-2071.

[11]. Adams, R.P. Identification of essential oils by Ion Trap Mass Spectrometry, $1^{\text {st }}$ Ed.; Academic press, New York,1989.
[12]. Jennings, W., Shibamoto, T. Qualitative analysis of Flavour and Fragrance volatiles by glass capillary chromatography. Academic Press, New York, 1980

[13]. Davies, N.W. Gas chromatographic retention indices of monoterpenes and sesquiterpenes on methyl silicon and Carbowax 20M phases. J. Chromatogr., 1990; 503: 1-24

[14]. Trease, G.E., Evans, W.L. Pharmacognosy. 16th ed.; London: Bailliere Tindall Ltd. pp. 60-75, 2009.

[15]. Ainsworth, E.A., Gillespie, K.M. Estimation of total phenolic content and other oxidation substrates in plant tissues using FolinCiocalteu reagent. Nat Produc., 2007; 2: 875-877.

[16]. Aiyegoro, O.A,, Okoh, A.I. Preliminary phytochemical screening and in vitro antioxidant activities of the aqueous extract of Helichrysum longifolium DC.BMC Complement. Altern. Med., 2010; 10: 21-28.

[17]. Karadag, A., Ozcelik, B. Saner S. Review of Methods to Determine Antioxidant Capacities. Food. Anal. Methods., 2009; 2: 41-60.

[18]. Ruch, R.J.1., Cheng, S.J., Klaunig, J.E. Prevention of cytotoxicity and inhibition of intercellular communication by antioxidant catechins isolated from Chinese green tea. Carcinogenesis., 1989; 10: 1003-1008.

[19]. Wettasinghe, M., Shahidi, I.F. Evening primrose meal: A source of natural antioxidants and scavenger of hydrogen peroxide and oxygen-derived free radicals. J. Agric. Food Chem., 1999; 47:18011812.

[20]. Garrat, D. C. The quantitative analysis of drugs. Chapman and Hall Ltd., Japan, 1964.

[21]. Bustanji, Y., Hudaib, M., Tawaha, K., Mohammad, M., Almasri, I., Hamed, S. In vitro xanthine oxidase inhibition by selected Jordanian medicinal plants. Jordan J Pharm Sci., $\quad 2011$; 4(1): 49-56.

[22]. Bhatwadekar, A.D., Ghole, V.S. Rapid method for the preparation of an AGE-BSA standard calibrator using thermal glycation. J. Clin. Lab. Anal.,2005; 19: 11-15

[23]. Kulkarni, O. et al. Ambiguity in the authenticity of traded herbal drugs in India: biochemical evaluation with a special reference to Nardostachys jatamansi DC. J. Herb. $\quad$ Med. Toxicol., 2010; 4(2): 229-235.

[24]. Howell, R.K. Phenols, ozone and their involvement in the physiology of plant injury. In: M. Dugger (Ed.), Air Pollution Related to Plant Growth, A.C.S. Symposium Series 3. Washington D C, pp. 94-105., 1974

[25]. Shukor, N.A.A., Ablat, A., Muhamad, N.A., Mohamad, J. In vitro antioxidant and in vivo xanthine oxidase inhibitory activities of Pandanus maryllifolius in potassium oxonate-induced hyperuricemic rats. Int. J. Food Sci. Tech., 2018; 53: 1476-1485.

[26]. Cho, Y.J., Ju, I.S., Yun, D.H., Chun, S.S., An, B.J., Kim, J.H. Biological activity of extracts from garden sage (Salvia officinalis L.) J Appl. Biochem., 2008; 51: 296-301.

[27]. Chen, Y.f., Roan, H.Y., Lii, C.K., Haung, Y.C., Wang, T.S. Relationship between antioxidant and anti-glycation ability of saponins, polyphenols and polysaccharides in Chinese herbal medicines used to treat diabetes. J. Med. Plants Res., 2011; 5: 23222331. 
Indo Global Journal of Pharmaceutical Sciences, 2020; 10(4): 77-87

[28]. Guedes, S., Vitorino, R., Domingues, M.R., Amado, F., Domingues, P. Glycation and oxidation of histones H2B and H1: in vitro study and characterization by mass spectrometry. Anal. Bioanal. Chem., 2011; 399: 3529-39.

[29]. Mahomoodally, F., Elalfi, Z. A., Venugopala, K. N., Hosenally, M. Antiglycation, comparative antioxidant potential, phenolic content and yield variation of essential oils from 19 exotic and endemic medicinal plants. Saudi J. Biol. Sci., 2019; 26(7): 1779-1788

Indo Global Journal of Pharmaceutical Sciences( ISSN 2249 1023; CODEN- IGJPAI; NLM ID: 101610675) indexed and abstracted in CrossRef (DOI Enabling), CNKI, UGC CARE Journal List, EMBASE (Elsevier), National Library of Medicine (NLM) Catalog (NCBI), ResearchGate, Publons (Clarivate Analytics), CAS (ACS), Index Copernicus, Google Scholar and many more. For further details, visit http://iglobaljournal.com 